Recenzje / Reviews

\author{
Zdzisław J. Winnicki \\ ORCID: 0000-0002-8636-2373 \\ zdzislaw.winnicki@uwr.edu.pl \\ Uniwersytet Wrocławski \\ Wydział Nauk Społecznych
}

\title{
Czas Apokalipsy, czyli atak na świat Zachodu \\ Józef Białek, Czas Sodomy, czyli zamach na cywilizacje, Wydawnictwo WEKTORY, Wrocław 2020, ss. 333
}

DOI: $10.34739 /$ doc.2021.18.21

Józef Białek, znany wydawca, przedsiębiorca, publicysta i działacz polityczny, edytor nie mainstrimowych książek w tym własnego autorstwa (np. Czas niewolników. Jak świat stał się własnościa kilku korporacji1), zaproponował swoja wersję genezy i skutków globalnych wydarzeń. Ich ukoronowaniem jest obecny stan spraw ogólnoświatowych, widzianych $z$ perspektywy zburzeń ideologicznych, społecznych, politycznych i ekonomicznych, jakie obserwujemy na tle tego, co autor nazywa nowa rewolucja.

Rewolucją, której - zdaniem Białka - jest ubezwłasnowolnienie narodów i państw poprzez planowe, miękkie, bez użycia siły, przejęcie władzy. Przez kogo? Tu autor stawia, jak sam podkreśla, hipotezy, które sytuuje na tle genezy zjawiska, upatrując $\mathrm{w}$ nim „Plan”, prowadzacy według niego do stopniowego rozmontowywania cywilizacji łacińskiej/zachodniej przez siły dążące do likwidacji suwerenności państw narodowych na rzecz „rządu światowego”, wykorzystującego do tego celu organizacje międzynarodowe w skali makro oraz sterowane zewnętrznie organizacje pozarządowe w skali mikro (państwowej). Celem jest niekontrolowana władza. Planem,

1 J. Białek, Czas niewolników. Jak świat stał się własnościa kilku korporacji, Wroclaw 2019. 
środkiem (spiskiem) jest metoda zapoczątkowana przez tajne stowarzyszenie Iluminatów. Dla realizacji Planu konieczne jest, jak stara się dowodzić Białek, zniszczenie cywilizacji (zachodniej).

Hipotezy, argumenty i konkluzje autora nie sa nowe. Przewidywali je autorzy teorii cywilizacji na czele $z$ polskim uczonym Feliksem Konecznym. Powstała liczna literatura $z$ gatunku, określanego przez ich przeciwników jako spiskowa teoria dziejów. Po próby opisu bardziej skutków niż genezy w literaturze polskiej sięgnął ostatnio w bestselerowych wydaniach swych ksiażek profesor Wojciech Roszkowski, publikując Roztrzaskane lustro. Upadek cywilizacji Zachodniej oraz Bunt barbarzyńców. 105 pytań o przyszłość naszej cywilizacji ${ }^{2}$. Pisał o tym zmarły niedawno Roger Scruton, zaś dwa lata temu Douglas Murray w książce Przedziwna śmierć Europy ${ }^{3}$.

Białek przedstawił swoja wizję genezy Planu, jego etapy ze szczególnym uwzględnieniem metod zastosowanych we współczesnej Polsce, a następnie założenia, projekty i decyzje realizowane globalnie w tzw. agendach ONZ. Na koniec hipotetycznie wskazał demiurgów zmian, do jakich zaliczył światowej rangi postepowe fundacje amerykańskie na czele $z$ organizacjami Rockefellerów i Gates'ów oraz Sorosa. Białek, podobnie jak Roszkowski, nie ma wątpliwości, że siły wrogie tradycji Zachodu maja dziś przewagę. $\mathrm{W}$ ich rękach sa światowe i krajowe finanse, media, a także w większości polityka, edukacja, nauka, sztuka. Nie tylko kreuja pieniądz, ale też kreuja „wartości”. Dzięki temu faktycznie dziś mają szanse rządzić światem (polityka globalna), a jak ostatnie wydarzenia, zwiazane $z$ fałszywa, jak zaznacza Białek pandemia, pokazuja, że „w dużym stopniu nim rządzą. I dodaje zaraz: „Jednak każda władza ma swój kres, również władza absolutna (...) im bardziej się rozrasta, tym więcej sił musi zużywać, aż w końcu upadnie. Zanim się jednak to stanie, musimy być przygotowani, aby ocalić to, co najlepsze" 4 . Jak to zrobić ? Autor wysuwa koncepcję budowania zwielokrotnionej „arki” cywilizacyjnej.

Jak wspomniano wyżej, słowami kluczowymi tez książki sa pojęcia: cywilizacja i władza. Białek skupia się na cywilizacji łaciń-

\footnotetext{
2 W. Roszkowski, Roztrzaskane lustro. Upadek cywilizacji zachodniej, Kraków 2019.

3 D. Murray, Przedziwna śmierć Europy. Imigracja, tożsamość, islam, Poznań 2017.

4 J. Białek, Czas Sodomy, czyli zamach na cywilizacje, Wrocław 2020, s. 331.
} 
skiej/zachodniej, przyczyny upadku której analizuje. Nie uwzględnia jednakże paradygmatu ogólnocywilizacyjnego, czyli relacji wszystkich siedmiu głównych cywilizacji świata, a o roli jednej, tj. rosyjsko-prawosławnej w ogóle nie wspomina. Dlaczego? Postawimy nasza hipotezę w tej mierze na końcu niniejszej recenzji, poprzestajac w tym miejscu na stwierdzeniu autora, że właśnie cywilizacja zachodnia jest zasadniczym przedmiotem jego rozważań. Wszędzie zreszta, gdy odnosi się do tego pojęcia ma na myśli i analizuje odniesienie tylko do tej cywilizacji. Wspomina wprawdzie o roli Chin, miejscu geopolitycznym Indii i Afryki, ale głównie jako o przedmiocie oddziaływań opisywanych przez niego środowisk antycywilizacyjnych, rozumianych wyłacznie jako skierowanych na destrukcję cywilizacji zachodniej.

Książka składa się z „Wstępu” i sześciu rozdziałów: I. „Nowy wspaniały świat, czyli eksterminacja białych ludzi”; II. „Dwa wieki rewolucji, czyli dzieje projektu rozmontowywania cywilizacji”; III. „Globalna indoktrynacja, czyli jak się truje umysły”; IV. „Pajęczyna, czyli kto, jak i za ile nami manipuluje”; V. „Sztab generalny, czyli kto i jak dyryguje globalna rewolucja”; VI. „Pajaki, czyli wszystkie nitki w tych samych rękach”. Książkę podsumowuje Zakończenie.

W rozdziale pierwszym J. Białek, przywołując liczne statystyki i wykresy, skupia się na przyczynach depopulacji białej rasy w państwach cywilizacji Zachodniej (Europa Środkowa, Zachodnia, USA, Kanada - nie podejmuje wątków australijskich i nowozelandzkich). Jako przyczyny wskazuje niechęć do reprodukcji, rosnąca bezpłodność, masowe popieranie różnych technik antykoncepcyjnych $z$ zalecana aborcja, wreszcie rozprzestrzeniająca się ideologia oraz praktyka gender i homoseksualizmu. Wszystko to połaczone $z$ obserwowana $w$ ostatnich latach praktycznie niehamowana na Zachodzie Europy „inwazja "uchodźców" stawia, jak uzasadnia Białek, „Zachód jako hospicjum”, a komentuje to nawiązujac do tytułu książki: „świat, w którym żyjemy przypominający biblijną Sodomę gdzie nie obowiazuja tradycyjne normy (...), a jedynym kryterium jest zysk i doraźna przyjemność. Jest to jednocześnie świat pełen rozpusty i lęku, przemocy i degeneracji, w którym zepsuci ludzie psują się jeszcze bardziej, bez nadziei na wyjście 
z sytuacji”5. Pyta przy tym, ,jak do tego doszło?”, odsyłając do swych analiz oraz wniosków w kolejnym rozdziale.

Rozdział II w ujęciu Białka to wskazania na skutki ateistycznego Oświecenia, czyli w głównej mierze materializm i ateizm, laicyzacja, praktyka i skutki terroru rewolucji francuskiej oraz ideologie i inżynierie społeczne, do jakich zalicza: pozytywizm według teorii Auguste’a Comte’a, marksizm klasyczny (materialistyczny) oraz techniki społeczne psychoanalizy według Freuda, z podkreśleniem podjętych przez innych freudystów triumfów - efektów "seksualnych obsesji” z zastosowaniem behawioryzmu jako „hodowli ludzi", zaprogramowanych na bodźce (np. reklamowe) lub reklamowanych jako jednie naukowe czy postępowe. Te oraz kolejne etapy i metody „rozmontowywania cywilizacji” autor oparł o znaczenie metody, która jest motywem przewodnim jego analiz i wniosków: metodę Iluminatów. W niej upatruje zasadniczy kierunek działania (metodę), przejęty następnie przez marksizm klasowy, a po jego odrzuceniu, jako mało skuteczny lub skuteczny lokalnie i czasowo - marksizm kulturowy, który według Białka (ale też innych analityków problematyki) wykreował poprzez neomaksistowską „szkołę frankfurcka” kulturowy proletariat zastępczy w ramach teorii i praktyki politycznej jako: feminizm, LGBT, a wreszcie równoległe: ekologizm, klimatyzm, które $z$ kolei znalazły realizacje w diagnozowanej przez Białka oenzetowskiej agendzie tzw. zrównoważonego rozwoju, unifikującej, jak podkreśla autor, świat globalnie. Poprzez zarówno merytoryczne rezolucje ONZ, jak i przez narzucanie sztywnych już norm prawa międzynarodowego, w jego wersji pozytywistycznej odrzuca się wszelki wpływ koncepcji prawno-naturalnych. Białek nazywa to budowa Novus Ordo Seculorum ${ }^{6}$.

Podkreślono wyżej Białka tezę o sprawczości i aktualności koncepcji Iluminatów ${ }^{7}$. O tym tajnym stowarzyszeniu (zakonie) na-

\footnotetext{
5 Ibidem, s. 51.

6 Ibidem, s. 134-138.

7 Uwaga: Autor niemal nie nawiąuje do sprawczości masonerii. Nie wyjaśnia tego, ale, jak należy sądzić, współczesne środowiska sprawcze raczej odrzuciły archaiczna i skomplikowanie rytualną, a zarazem najwidoczniejszą formułę masońska na rzecz nieuchwytnej organizacyjnie metody iluminackiej. Podobnie Białek nie nawiąuje też do roli Zakonu Syjonu, w jaki poprzez finanse przekształcić się mieli Templariusze. Nie ma też wzmianki o czwartej formule tajnych organizacji - Assasynów, do jakiej nawiazuja zorganizowane integrystyczne środowiska islamskie jako Al Kaida czy ISIS. Chyba, że przyjąć, iż Józef Białek uznał, iż pierwsi to wielka
} 
pisano wiele. Białek umiejscawia je w omawianym rozdziale dla wskazania roli, jaka grupa ta odegrała w projekcie (metodzie) systemu kontroli i nadzoru nad kształtowaniem pożąanych wartości (antywartości) społecznych w warunkach zaprojektowanej i wdrażanej w rewolucyjnej Francji - i likwidacji religii (chrześcijańskiej), uznanej za główną oporę przed cywilizacyjna destrukcją. Zakon Iluminatów założony 1 maja 1776 r. przez profesora prawa i historii Adama Weishaupta, którego credo brzmiało: „książęta i narody znikna z powierzchni ziemi bez użycia przemocy, rasa ludzka stanie się jedną rodzina, a świat siedziba ludzi rozumnych"8.

Metoda zaproponowana przez Weishaupta było zastapienie wyłącznej władzy nad majątkiem, władzą nad „kontrolą ludzkich sumień", a zatem jak to należ rozumieć współcześnie = nad kulturą, co właśnie przejął jako metodę marksizm kulturowy. Próba praktyczna zastosowania tej metody był przebieg i rozwiąania polityczne, wprowadzone po raz pierwszy masowo przez rewolucyjne rządy jakobinów we Francji. Zakon Iluminatów upadł, jakobini tak$\dot{z}$ e, ale pozostała metoda. Jej elementy ze wskazaniem na postaci demiurgów, jacy odegrali rolę w „dopinaniu” i stosowaniu Planu Weishaupta ukazane sa przez autora recenzowanej monografii w dalszej części rozdziału.

Rozdział III to wskazanie, jak wielowektorowo, wielowątkowo i masowo postępuje, jak zaznacza Białek, tytułowe „trucie umysłów” po to, by zaistniała przywołana wyżej „kontrola ludzkich sumień”. Do jej realizacji, jak dowodzi autor, używane są: powszechny system nowoczesnej edukacji, poprawne politycznie uniwersytety, masowa pop-kultura, zastępowanie tradycyjnych pojęć tzw. nowomowa, przekształcana w prawnie umocowana obowiązkowość metoda stosowania i penalizacji „politycznej poprawności”, wreszcie postępująca destrukcją Kościoła katolickiego, zaprogramowana w latach 60. XX wieku tzw. otwarciem (Agiornamento) soboru Watykańskiego II-go, a skutkujaca między innymi skrajnie destrukcyjnymi wpływami „lawendowej mafii” w Kurii Rzymskiej, seminariach duchownych i strukturach kościołów lokalnych. Temu ostatniemu zjawisku Józef Białek poświęca więcej uwagi zaznaczając, że

finansjera, o jakiej pisze w dalszych częściach swej analizy, a drugich potraktował w ramach efektu współczesnego naporu tzw. uchodźców na Europę Zachodnią. 8 F. Wheen, Jak brednie podbity świat, Warszawa 2005, s. 176. 
ma to znaczenie fundamentalne dla destrukcji cywilizacji łacińskiej/zachodniej, gdyż jej główny depozytariusz - Kościół katolicki i jego nauczanie - zostały uznane przez „kapłanów” Novus Ordo Seculorum za ostatnią barierę chroniaca cywilizację przed wizja i praktyka Nowego Wspaniałego Świata, który z przewidywań Huxley'a staje się płynnie i coraz szybciej wdrażaną rzeczywistością jak trawestuje Białek: metoda podgrzewania żaby.

I stało się, jak pisze dalej, gdyż ,jeśli zestawimy wartości kulturowe lat dwudziestych i trzydziestych XX wieku $z$ obecnie propagowanymi wartościami, zobaczymy, że dokonała się diametralna zmiana, wskutek której dawne antywartości stały się dziś podstawa nowej moralności”9 (pederastia, wulgarność, nagość, pornografia). I zaznacza dalej „Takie właśnie wzorce znajdujemy wszędzie wokół siebie. Epatuja nimi reklamy, filmy i seriale, kolorowe gazety i tanie powieści, programy telewizyjne oraz internetowe media społecznościowe"10 i podsumowuje: „cena za życie wbrew naturze jest degeneracja i rozpad"11. Cóż do tego dodać? Zachęcić do przemyślenia nie nowatorskich przecież tez Józefa Białka, zawartych w jego książce.

W rozdziale czwartym autor uświadamia czytelnika, „kto, jak i za ile nami manipuluje”. Mowa jest w nim o niezwykle w ostatnich latach rozwiniętej sieci społecznej, sponsorowanej przez demiurgów Nowego Wspaniałego Świata, osławionych organizacji pozarządowych (NGO'sów), nie podlegających kontroli państwa narodowego i finansowanych w lwiej części przez ośrodki zagraniczne (też w znaczacej mierze pozarzadowe), ale także przez rządy narodowe motywowane do tego przez globalne organizacje międzynarodowe, zarówno pozarządowe, jak i rządowe. Białek podkreśla (powszechnie zreszta zauważalna) metodę, w wyniku której odbywa się „rewolucja kulturalna”, sterująca ludzkimi umysłami i streszcza to tak: „W dzisiejszym świecie rolę podstawowych komórek rewolucyjnych przejęły tzw. organizacje pożytku publicznego, a więc stowarzyszenia i fundacje. To dzięki nim prowadzona jest powszechna indoktrynacja"12. Działaja, jak podkreśla autor, pod szczytnymi powierz-

\footnotetext{
9 Ibidem, s. 116.

10 Ibidem, s. 117.

11 Ibidem.

12 Ibidem, s. 182.
} 
chownie celami, jak np. działania charytatywne, „zdobywając kolejne przyczółki dla władzy rewolucji (...) używając haseł [pozytywnych] w rodzaju "demokracja», "tolerancja», "równość", "różnorodność», "wielokulturowość", "integracja" i tak dalej", oraz o zabarwieniu negatywnym, tj. „przeciw: "dyskryminacji», "nietolerancji", "nierówności", "homofobii", "wykluczeniu", "Szowinizmowi" i tak dalej"13.

Nie miejsce tutaj na objaśnianie powyższego. Jest ono obecne we, wprawdzie rozproszonym, niszowym, ale dostępnym dla zainteresowanych materiale, zarówno naukowym, jak i publicystycznym. Ważnym natomiast ustaleniem autora jest enumeratywne wymienienie, chyba wszystkich najważniejszych $z$ punktu widzenia analizowanego tematu, stowarzyszeń i fundacji, działających w Polsce. Jak ukazuje Białek, jest to skala i zasięg ogromny! Omawia on podstawowe cele i zasady działania najistotniejszych $z$ punktu widzenia wdrażania „rewolucji kulturowej” instytucji, od Fundacji Batorego poprzez organizacje typu gender i LGBT, klimatystów, wegan. Jeszcze istotniejsze dane, jakie przy tej okazji przytoczył dotycza finansowania $\mathrm{w}$ tym zewnętrznego oraz niekontrolowanego przez państwowe organy nadzoru finansowego (sic!). Sa to kwoty oszałamiajace. I tak np. w ciagu 14 lat sama UE wydała, jak pisze Białek, na „propagowanie rewolucji kulturowej” w Polsce łacznie 25 mld euro ${ }^{14}$. I dodaje, że Unia nie jest jedynym ze sponsorów. Wskazuje na tych innych w kolejnych rozdziałach, tutaj wymieniając jako zasadnicze m.in. Open Society Foundations G. Sorosa, ILGE Europe czyli Międzynarodowe Stowarzyszenie Gejów i Lesbijek oraz takie fundacje, jak Saplinq, holenderska Mama Cash, Het Actiefonds, Fundacja im. H. Boella, szwedzki Sigrid Rausing Trust, belgijska fundacja Evens, Arcus Foundation, Global Fond for Women. Wymienia też $\mathrm{w}$ tym kontekście sponsorów krajowych państwowych (ministerstwa) i samorzadowych. Sa to dane zaskakujace, na co dzień nieznane obywatelom naszego państwa. Pełnią, jak podkreśla Białek, „rolę podstawowych komórek rewolucyjnych w poszczególnych państwach Zachodu"15. Od siebie dodajmy, że na ogół nie działają w obrębie pozostałych cywilizacji np. islamskiej czy chińskiej.

\footnotetext{
13 Ibidem.

14 Ibidem, s. 199.

15 Ibidem, s. 218.
} 
Kto tym „steruje” centralnie ? Józef Białek opowiada o tym w rozdziale piatym: „Sztab Generalny, czyli kto i jak dyryguje globalna rewolucja”. Na wstępie autor uprzedza spodziewaną krytykę zaznaczając: „Jeśli chce się dziś ośmieszyć pewne poglądy, przypina się im łatkę "teorii spiskowej". Faktem jednak jest, że dzieje świata to ciąg spisków i niejawnych układów. Jeśli ktoś oskarża kogoś o głoszenie teorii spiskowej, możemy być pewni, że boi się ujawnienia prawdy [o sobie]"16. Według Białka „sztabem” były i sa organizacje międzynarodowe od komunistycznych Międzynarodówek Robotników, ale też, i tu duże zaskoczenie dla „niewtajemniczonych”, poprzez Ligę Narodów do współczesnej Organizacji Narodów Zjednoczonych. Ich cecha, jak twierdzi, była natura organizacji i działania oparte „o język nowomowy”.

Piękne słowa i piękne zasady, ale Józef Białek zaznacza: „Nie można się dać na to nabrać: to tylko przykrywka, a prawdziwym celem jest władza"17. Dla udowodnienia swych tez autor przywołuje postaci, które intensywnie pracowały nad urzeczywistnieniem idei „rządu światowego”, który na obecnym etapie pozytywizuje prawnie cele organizacji poprzez konwencje prawa międzynarodowego publicznego, organizowanie Światowych Konferencji wytyczajacych politykę ONZ, a zatem i kodyfikacje prawa $z$ udziałem państw członkowskich. Wymienia jako przykłady („narzędzie propagandy ONZ") Światowe Konferencje w sprawie Kobiet (od 1972 r. do konferencji pekińskiej z roku 1995 zalecającej ogólnoświatowa politykę gender). Potem precyzuje kolejne zarzuty wobec agend ONZ, narzucających globalna politykę unifikacji zagadnień ochrony zdrowia, edukacji, nauki, nauczania oraz preferencji kulturowych (WHO, UNESKO, FAO, MFW, WTO, WEF). Białek wskazuje, że owa globalna unifikacja dotyczy metod i środków leczenia (szczepienia!), narzucania edukacji seksualnej, propagowania ideologii gender i LGBT, finansowania i kredytowania np. upraw żywności genetycznie modyfikowanej, zasad kontroli handlu międzynarodowego, itd. W książce znajdziemy opisy szczegółowych polityk, których celem jest, jak twierdzi Białek, podporządkowanie państw polityce globalnej, w tym nie tylko samych organizacji, bo te, jak wynika $z$ tez autora, służą światowym korporacjom, a organizacje między-

\footnotetext{
16 Ibidem, s. 223.

17 Ibidem, s. 229.
} 
narodowe sa ich „pasem transmisyjnym” do przymuszania państw oraz społeczeństw do wyzbycia się suwerenności politycznej i wolności obywatelskiej na rzecz zunifikowanej i wszechstronnej polityki globalnej. Koncerny i korporacje sa bowiem silniejsze (bogatsze) niż rządy narodowe.

Tu należy podjać częściową polemikę $z$ autorem, który prawidłowo wskazując na politykę wymienionych agend ONZ na rzecz globalizacji wymuszonego postępowania społeczności międzynarodowej, zdaje się zapominać o pewnych okolicznościach. Zgromadzenie Ogólne ONZ nie ma kompetencji prawodawczych, a samo prawo międzynarodowe nie działa automatycznie $z$ samej swojej treści normatywnej. Rezolucje $Z O$ sa wskazówkami dla agend i propozycją dla społeczności międzynarodowej (państw), a konwencje (kodyfikacje) prawa międzynarodowego wchodza w życie wyłącznie w stosunku do tych państw, które je ratyfikuja. Bo normy tego prawa wprowadzane sa w życie w stosunku do państw (albo niewprowadzane) poprzez zgodę na to prawa krajowego (ustawy wyrażające zgodę na związanie się i ratyfikację przez głowę państwa). Czym innym jest nacisk, na ogół skuteczny bo uwarukowany np. funduszami (pożyczki, kredyty, dotacje), a czym innym związanie się prawem międzynarodowym. Nie ma możliwości bezpośredniego narzucenia tego prawa państwom, które odmówią związania się jego normami. Jaka jest praktyka ? To już inna dyskusja.

Druga wątpliwością, zgłaszaną do treści omawianego rozdziału jest wybiórcze przywołanie postaci, które, mając wpływ na kształtowanie się instytucji, o których pisze Białek, nie wyczerpuja listy. Chociaż wskazania na rolę doktryny prawnej Hansa Kelsena, roli Roberta Mosesa w instalacji siedziby ONZ w Nowym Jorku czy donacji jej siedziby gruntowej przez J. D. Rockefellera sa uzasadnione, jednak sa to kwestie do odrębnego omówienia, niekoniecznie w kontekście hipotez oraz tez rozważanych przez Józefa Białka w omawianej książce. Na zakończenie autor zamiast podsumowania przywołuje szokująca tezę autora książi zatytułowanej Ukryte oblicze ONZ Michela Schooyansa, księdza profesora uniwersytetów w Leuven i Sao Paulo: „W środowiskach zwiazanych z ONZ zniszcze- 
nie narodów stanowi cel, którego realizacja pociagnie za sobą definitywną likwidację antropocentrycznej koncepcji praw człowieka"18.

Tak też to widzi Józef Białek, który w ostatnim szóstym rozdziale zadaje końcowe, „ostanie pytanie, na które chcemy odpowiedzieć w tej książce (...) kim sa ci ludzie cienia”, poruszajacy marionetkami, za jakie uznaje na podstawie przedstawionych wyżej hipotez i tez organizacje międzynarodowe, rządowe i pozarządowe. Ponieważ byłoby to bardzo poważnym oskarżeniem konkretnych osób, Józef Białek zastrzega, „że większość przedstawionych tu opinii ma zaledwie status hipotez, które warto jednak zbadać choćby po to, aby przestać naiwnie wierzyć, że rzeczy na świecie tocza się same $z$ siebie, przez nikogo niekontrolowane" ${ }^{19}$. Wbrew takiemu założeniu Białek wskazuje nie tylko owych ludzi cienia, nie do końca zreszta, jak się okazuje, aż tak „zacienionych”. Wskazujac postaci i znów (sic!) ich fundacje, autor ilustruje ich globalna działalność poprzez ukazywanie sfer działania w dziedzinach polityki: zdrowia, żywności, populacyjnej, finansowej i dodajmy, ostatnio tzw. „praworządności”, zgodnie $z$ celem, jaki według niego, przyświeca demiurgom budowy Nowego Wspaniałego Świata: władza na tymi dziedzinami w skali globalnej. Szczególna rolę wiąże autor z działaniami Fundacji Rockefellera, skupionymi, jak to wykazuje, na „kontroli populacji poprzez nadzór nad systemem zdrowia i medycyna”"20, co ma się przejawiać w nadzorze (iluminatyzm!) nad kontrola urodzin $z$ uwzględnieniem aborcji, sterylizacji i eugeniki, przemysłu farmaceutycznego i produkcją żywności oraz „kontrola umysłu" w dziedzinach mediów, edukacji i nauki poprzez finasowanie i wspieranie instytucji tworzonych przez tę fundację. Swoje tezy autor dokumentuje wykazami światowych struktur powiazanych $z$ agendami ONZ, realizujacymi na przykład tzw. zielona rewolucję, upowszechniajaca techniki GMO. Wreszcie Białek dochodzi do zasygnalizowania zjawiska, z którym świat boryka się obecnie $z$ globalna pandemia groźnego wirusa, co miałoby według autora na celu: „wprowadzenia globalnego poziomu strachu obniżającego odporność; wywołało antagonizmy wewnątrz państw; dało pretekst

18 Ibidem, s. 242. Józef Białek zdaje się zapominać, że od 1964 r. Stolica Apostolska jako Państwo Miasto Watykan posiada stałego obserwatora w ONZ w randze nuncjusza.

19 Ibidem, s. 280.

20 Ibidem, s. 281. 
do wprowadzania stanów nadzwyczajnych w tym izolacji społecznej; wyeliminowało małe i średnie przedsiębiorstwa w interesie wielkich koncernów i gospodarki bezpośrednio kontrolowanej przez państwa; poddanie całej światowej populacji szczepieniom prewencyjnym oznaczającym pelną kontrolę na populacją" ${ }^{21}$ [podkreślenie ZJW]. Jako dowód na tę spełniająca się na naszych oczach wizje Białek przywołuje „wewnętrzny dokument Fundacji z roku 2010", zawierajacy Scenariusze przyszłego rozwoju technologicznego i międzynarodowego, co miało/ma być zwiąane $z$ nadejściem w przyszłości pandemii nieznanego wirusa", prognozowanego w tym dokumencie na rok 2012. Białek przytacza tę prognozę (scenariusz, expressis verbis ${ }^{22}$ ), twierdząc w zakończeniu: „Nadszedł rok 2020 i scenariusz, opracowany dekadę wcześniej, wszedł w fazę realizacji (...) [a] Władcy tego świata mają bowiem wyraźne dążenie: zmniejszyć liczbę ludności, aby było łatwiej rządzić”23.

Bardzo mocne tezy (choć wcześniej Autor zaznacza, że są to hipotezy) skorelowane $z$ stanem wywołanym przez Covid-19! W końcówce rozdziału, a zarazem ksiaż̇ki Białek uzupełnia wyżej zarysowana hipotezę działaniem entuzjasty szczepionek, czyli Billa Gatesa i jego Fundacji oraz globalnego koncernu informatycznego. Fundację tę Białek kwalifikuje jako „klon” Fundacji Rockefellera. Podaje przy tym statystykę wydatków (inwestycji?) Gatesa w dziedzinach takich jak: kontrola chorób zakaźnych, badania nad HIV i AIDS, kontrola gruźlicy, opieka zdrowotna i reprodukcyjna, badania nad statusem planowania rodziny, badania w dziedzinie nowych technologii w rolnictwie, promowanie „świadomości rozwoju” [?] i technikę zarządzania w wyżej wymienionych sferach. Ma to, według Białka, wzmocnić światowa politykę przede wszystkim depopulacyjna. Działania przywoływanej (przywoływanych) Fundacji realizowane sa, jak podkreśla autor, „przez ludzi Gatesa i Rockefellerów" w strukturach agend ONZ, takich jak na przykład UNICEF, FAO i WHO. Do tego dochodza działania w zakresie totalnej informatyzacji z wykorzystaniem technologii $5 \mathrm{G} \mathrm{i}$... powszechna smartfonizacja, używana do indoktrynacji i kontroli praktycznie każdego

\footnotetext{
21 Ibidem, s. 300.

22 Ibidem, s. 302-303.

23 Ibidem, s. 303.
} 
człowieka na naszym globie. Dalszym ciagiem może być już tylko czipowanie ${ }^{24}$.

Tak oto zdaniem Białka zostaje wdrożony model Weishaupta: władza przez kontrolę nad zdruzgotaną cywilizacją łacińska//zachodnia, która zastapi (?) nowy model „cywilizacji naukowotechnicznej”. Że to jest możliwe, Białek wskazuje już działający w praktyce cywilizacyjny, współczesny model chiński. Istna Apokalipsa i spełnienie „proroctwa” Huxleya, jakie oglądaliśmy dotąd wyłącznie w filmach science fiction. Czy to się dzieje naprawdę? Białek twierdzi, że tak. Jak wiemy, nie tylko on. Książka Józefa Białka to jeden $z$ bardziej wyrazistych głosów (manifestów) w tej nierównej dyskusji, jaka jeszcze istnieje, wobec dominacji absolutnej mediów sprzyjających nadchodzacej przemianie cywilizacyjnej.

Czy autor widzi alternatywę i zatrzymanie trendu jaki, według niego, nieuchronnie nie tylko nadchodzi, ale wręcz wkracza $\mathrm{w}$ fazę bezpośredniej realizacji? O jednej nadziei, jaką Białek upatruje w „przeciążeniu systemu” już wspomniano. Wydaje się jednak, że autor wątpi w taki rozwój sytuacji. Pisze bowiem, że „niewatpliwie siły wrogie tradycji Zachodu maja dziś przewage we wszystkich wskazywanych w książce aspektach wpływu czy wręcz władzy”. Wiara Białka w „kres władzy absolutnej”, w „zużycie się” bazuje na obserwacji historycznie upadłych imperiów.

Faktycznie zdegenerowane lub „przeciązone” imperia upadały. Imperium trwa, gdy jest agresywne. Zdegenerowane i bierne, upada. Przykładów można przytaczać wiele. Józef Białek wskazuje w tym zakresie na upadek Cesarstwa Rzymskiego. Rzecz w tym, że imperium to jednostka polityczna, a cywilizacja to struktura kulturowa. Jako taka upaść może, ale nie musi, o czym jak wielokrotnie tutaj wskazywaliśmy świadczą losy cywilizacji chińskiej. Jest ona agresywna, a po wykorzystaniu modernizacji typu zachodniego, skuteczna. Rzym nie był cywilizacja, był imperium. Cywilizację łacińską ukształtowało zachodnie chrześcijaństwo, zaś jej główne wartości, jak przypomina Białek, przechowały w europejskich „wiekach ciemnych” (V-VIII wiek) zakony, nazwane przez autora „arkami” kultury i wartości. O budowe systemów „arki” apeluje zatem Józef Białek. Apeluje o tworzenie wspólnot ludzkich, które „połączą

24 Ibidem, s. 321-322. 
idee i wartości oraz wspólne cele”25. Ma to być swoisty „drugi obieg, alternatywnej sieci relacji samopomocy i samokształcenia, wzmacniający jego członków, dający im poczucie sensu i wsparcie w zderzeniu $z$ oficjalna władzą"26. Białek proponuje „długi marsz” uważając, że skoro raz się to naszej cywilizacji udało, może się udać ponownie. Wydaje się, że Józef Białek już taką własną „arkę” stworzyl. Jest nia Wydawnictwo WEKTORY, w którym od lat wydaje książki, jakie nie mogłyby ukazać się gdzie indziej. Wokół WEKTORÓW buduje także środowisko na miarę niewielkiego, także o zasięgu międzynarodowym, think tanku. Jest więc nie tylko teoretykiem sprawy, która głosi, ale realizatorem działan, jakie na własną miarę animuje. I trzeba dodać, że takie „arki” istnieja (wydawnictwa, think tanki, czasopisma, środowiska). Czy okażą się skuteczne?

Książka Białka jest manifestem tez i hipotez. Nie jest systemem filozoficznym ani monografia o charakterze właściwym opracowaniom naukowym. Jest jednakże ważnym, choć momentami szokującym głosem dyskusji nad zasadniczymi problemami, $z$ jakimi praktycznie spotyka się niewatpliwie zmieniajacca się, a zatem upadajaca cywilizacja Zachodu, taka, jaka znaliśmy przez wiele stuleci. Modernizacja trwa, lecz westernizacja klasyczna upada. Trzeba o tym dyskutować, wyjaśniać i promować jako idee obronne. To między innymi jest celem książki Józefa Białka. Jaki będzie odzew na Czas Sodomy? Można wskazać dwie możliwości. Jeżeli zdobędzie rozgłos, mainstream uzna to szyderczo za kolejny przypadek jeszcze jednej teorii spiskowej. Jeśli książka rozejdzie się tylko w „arkach”, mainstream ja tradycyjnie zamilczy. Bo Plan, ujawniony w hipotezach Józefa Białka jest bowiem albo tak oczywisty i jasny, że wręcz nieprawdopodobny, by weń uwierzyć, albo jest mitem albo Prawdą. „Arki” będą czytać, dyskutować i przekazywać w swoich kręgach. Czy dotrze szerzej - zobaczymy po efektach dystrybucji i reakcjach.

$$
* * *
$$

Na bazie tez i hipotez Józefa Białka można i należy postawić zatem już w tym miejscu kilka uwag, korygujacych lub uzupełniających. Białek pisze o „zamachu na cywilizację”, utożsamiając ja

25 Ibidem, s. 331.

26 Ibidem. 
przede wszystkim $z$ cywilizacja zachodnią. To jej kres wieszczy, wskazując na metody i środki, jakie sa podejmowane przez opisywane przez niego środowiska oraz instytucje „antycywilizacyjne”. Niemniej wiemy przecież, że obok cywilizacji Zachodniej istnieja inne, jak choćby wymienione przez Samuela Huntingtona: rosyjsko-prawosławna, islamska, hinduistyczna, chińska, latynoamerykańska i leżąca niejako na uboczu japońska. Pozostaja one w interaktywnym „zderzeniu” i rywalizacji. Mająca zastąpić zachodnia „cywilizacja naukowo-techniczna”, o ile powstanie, zapewne nie zdominuje w całości pozostałych. Przekaże modernizację, ale nie zdominuje neowesternizacja. A więc, cywilizacje (w liczbie mnogiej) trwaja i wygląda na to, że w większości, w przewidującym czasie przetrwaja. Tylko zachodnia ulega autodestrukcji i naporowi zewnętrznemu. Genetyczny Demiurg tej autodestrukcji, na którego metodę jako aktualna powołuje się Białek, Weishaupt prawdopodobnie nie uznawał istnienia pozostałych, zreszta za wyjatkiem Rosji, gdyż były zdominowane w XVIII i XIX wieku przez cywilizację zachodnia. Metoda działań cywilizacji jako takich jest znana - usiłują zdominować pozostałe. Czy któraś z nich upadła zachodnia zdominuje (niekoniecznie siłowo)? Chyba, że jakimś cudem (sic!) zachodnia przegrupuje siły i się odrodzi we współpracy z którąś $z$ pozostałych. To jednak kwestia, której Józef Białek chyba świadomie nie podejmuje, koncentrując się na cywilizacji zachodniej (Europa Zachodnia, USA i Kanada oraz Australia $z$ Nową Zelandia). To do niej odnosi przede wszystkim swoje tezy i dowody.

Dlatego, mając na względzie przyszłość książki, należy zasugerować, by ewentualne drugie uzupełnione wydanie uzyskało zmodyfikowany tytuł: nie Sodoma, co sugeruje opowieść o zboczeniach seksualnych, ale Apokalipsa. Podobnie należy bezwzględnie zmienić szatę graficzna okładki. Jest pretensjonalna i nie oddaje idei zawartych w ksiażce. Zaproponować można: Czas Apokalipsy czyli zamach na cywilizacje Zachodnia. Podobnie zalecić można dokonanie przeglądu i korekty ilustracji. Usunąć sprawiające wrażenie pretensjonalnych karykatur, gdyż negatywnie wpływaja na odbiór zarówno tekstu, jak też znaczenie niezwykle wymownych schematów, zestawów i tabel prezentujących twarde dane, w oparciu o jakie Białek buduje hipotezy i tezy. Po co wystawiać się na 
złośliwości przeciwników, dając im argumenty dla ośmieszania, co, jak można przewidywać, i tak nastapi ${ }^{27}$.

\section{Bibliografia / References}

Białek J., Czas niewolników. Jak świat stał się własnościa kilku korporacji, Wrocław 2019.

Białek J., Czas Sodomy, czyli zamach na cywilizacje, Wrocław 2020.

Murray D., Przedziwna śmierć Europy. Imigracja, tożsamość, islam, Poznań 2017.

Roszkowski W., Roztrzaskane lustro. Upadek cywilizacji zachodniej, Kraków 2019.

Wheen F., Jak brednie podbity świat, Warszawa 2005.

27 I drobna uwaga korekcyjna: na str. 203 autor, prezentujacc sylwetkę Aleksandra Smolara na tle ówczesnego środowiska opozycyjnego, błędnie określa część tego środowiska $z$ okresu tzw. wydarzeń marcowych 1968 r. jako tzw. „partyzantów”. Błąd: to byli tzw. „komandosi”, a „partyzantami” - ludzie PZPR skupieni wokół Mieczysława Moczara. Prawdopodobnie $z$ pośpiechu wydawniczego sa także w publikacji pomyłki w numeracji stron. 
